\title{
Pengaruh Penggunaan Media Komik Terhadap Hasil Belajar Peserta Didik Kelas III Tema I Subtema I Di Mi The Noor
}

\author{
${ }^{1}$ Nur Haqiqi, ${ }^{\text {BBenny Angga Permadi }}$ \\ 1,2 Institut Pesantren KH. Abdul Calim Mojokerto \\ *E-mail korespondensi: 1nurhaqiqi626@gmail.com, 2bennyangga68@gmail.com
}

\begin{abstract}
Abstrak
Proses belajar mengajar yang dilakukan oleh guru disekolah MI The Noor khususnya dalam penggunaan media pembelajaran masih sangat kurang, hal ini dibuktikan dari hasil belajar peserta didik yang masih banyak dibawah KKM, selain itu saaat proses belajar mengajar dilakukan, peserta didik kurang bersemangat dalam mengikuti pelajaran, hal ini sangat berpengaruh terhadap pemahan peserta didik sehingga mengakibatkan kurang tercapainya pembelajaran yang diinginkan.Oleh karena itu dalam proses pembelajaran harus mampu memilih media yang tepat, media komik sangat cocok untuk digunakan dalam pembelajaran, karena media komik dapat membangkitkan semangat peserta didik dalam proses pembelajaran, dan juga materi yang disampaikan dengan media komik sangat jelas dan simpel sehingga akan berpengaruh terhadap hasil belajar peserta didik.Penelitian ini bertujuan untuk mengetahui pengaruh penggunaan media komik terhadap hasil belajar peserta didik kelas III Tema I Subtema I. Design penelitian yang dilakukan adalah One Group Pretes Postes. Populasi penelitian terdiri dari 88 peserta didik kelas I, II, III, IV, V, VI dan 16 Peserta didik kelas III sebagai sampel. Hasil analisis data dengan menggunakan uji Paired sample t-tes didapatkan nilai Sig. (2-tailed) sebesar 0,000, yang artinya dari hasil uji tersebut didapatkan nilai lebih kecil dari 0,05, sehingga dapat disimpulkan bahwa terdapat pengaruh dalam penggunaan media komik terhadap hasil belajar peserta didik.
\end{abstract}

Kata kunci: Media Komik, Hasil Belajar.

\begin{abstract}
The teaching and learning process carried out by teachers at MI The Noor school, especially in the use of learning media is still very lacking, this is evidenced by the learning outcomes of students who are still much below the KKM, besides that when the teaching and learning process is carried out, students are less enthusiastic in participating in lessons, This is very influential on the understanding of students, resulting in less achievement of the desired learning. Therefore, in the learning process, one must be able to choose the right media, comic media is very suitable for use in learning, because comics media can arouse the enthusiasm of students in the learning process, and also the material delivered with comic media is very clear and simple so that it will affect the learning process. student learning outcomes. This study aims to determine the effect of using comics media on the learning outcomes of third-grade students, Theme I, Subtheme I. The research design is One Group Pretest Posttest. The study population consisted of 88 students in classes I, II, III, IV, V, VI and 16 students in class III as samples. The results of data analysis using the Paired sample $t$-test test obtained the value of Sig. (2-tailed) of 0.000, which means that the test results obtained a value smaller than 0.05, so it can be concluded that there is an influence in the use of comic media on student learning outcomes.
\end{abstract}

Keywords: Comic Media, Learning Outcomes.

https://doi.org/10.32665/jurmia.v2i1.274 


\section{PENDAHULUAN}

Pendidikan merupakan hal yang sangat penting untuk mengembangkan dan meningkatkan kemampuan seseorang. Hal tersebut sesuai dengan fungsi dan tujuan Undang-Undang Sistem Pendidikan Nasional. Pendidikan Nasional berfungsi untuk mengembangkan kemampuan seseorang dan membentuk watak seseorang serta peradaban bangsa yang bermartabat, dalam rangka mencerdaskan kehidupan bangsa, bertujuan untuk berkembangnya potensi peserta didik, agar menjadi manusia yang beriman dan bertakwa kepada tuhan yang maha esa, berakhlak mulia, sehat, berilmu, cakap, kreatif, mandiri, dan menjadi warga Negara yang demokratis dan bertanggung jawab (UUD RI RI No. 41 1999).

Fungsi dan tujuan dari Pendidikan Nasional tersebut tentunya tidak terlepas dari yang namanya guru dan peserta didik. Peran guru dalam dunia pendidikan sangatlah penting yaitu merencanakan proses belajar mengajar agar tercapainya tujuan pembelajaran. Dalam merencanakan proses kegiatan pembelajaran, guru juga harus memperhatikan karakteristik seorang peserta didik, agar proses pembelajarannya bisa berlangsung dengan baik.

Proses belajar mengajar kehadiran media mempunyai peranan yang sangat penting, sebab dalam proses belajar mengajar ketidak jelasan bahan ajar yang digunakan oleh guru untuk peserta didik, dapat dibantu dengan menghadirkan media sebagai perantara untuk mentrasfer ilmu. Kerumitan bahan ajar yang akan disampaikan kepada peserta didik dapat disederhanakan dengan bantuan media. Dalam kegiatan pembelajaran banyak sekali faktor yang menunjang untuk mencapai keberhasilan dalam kegiatan pembelajaran tersebut, salah satu faktor untuk menunjang keberhasilan itu ialah faktor media.

Media yang hendak digunakan seharusnya mampu membuat proses belajar mengajar menjadi lebih menyenangkan dan menarik, sehingga peserta didik mudah memahami apa yang disampaikan oleh guru. Media pembelajaran yang bervariasi dapat menumbuhkan semangat peserta didik dalam proses belajarnya, dengan bertambahnya semangat peserta didik tentunya dapat mempengaruhi hasil belajar yang diperoleh. Oleh karna itu seorang guru harus mampu memilih dan merencanakan media apa yang cocok untuk digunakan dalam pembelajaran. Dalam hal ini media yang dimaksud adalah media gambar berbentuk komik. Media komik merupakan salah satu media visual yang menarik dan dapat menumbuhkan semangat peserta didik dalam proses belajarnya. Komik adalah bentuk kartun yang menggambarkan karakter serta memerankan cerita berurutan yang dihubungkan dengan gambar dan dirancang agar pembaca dapat dengan mudah untuk memahami (Riyana and RI 2012).

Media komik merupakan media yang kreatif dan efektif untuk digunakan, media komik mampu menciptakan suasana belajar mengajar menjadi menyenangkan melalui cerita bergambar yang menarik dalam pembelajaran. Saat peserta didik sudah merasa senang dengan adanya bantuan media pembelajaran tentunya belajar peserta didik juga lebih semangat dan menyenangkan, sehingga akan mempengaruhi hasil belajar peserta didik tersebut.

Hasil belajar merupakan bagian terpenting dalam pembelajaran. Ahmad Susanto(Ahmad n.d.) mengatakan bahwa makna hasil belajar ialah perubahan yang terjadi pada peserta didik baik dari segi kognitif, afektif, maupun psikomotorik sebagai bentuk dari proses belajar (Nurmawati 2016). (Suttrisno 2021) dalam penelitiannya menambahkan bahwa Hasil belajar dan motivasi belajar peserta didik dapat ditingkatkan melalui banyak cara misalnya penggunaan alat peraga, media pembelajaran maupun model belajar yang disesuaikan dengan kondisi kelas dan juga 
peserta didiknya (Anon n.d.). Dengan adanya hasil belajar, seorang guru akan mudah untuk mengetahui seberapa besar kemampuan peserta didik dalam menangkap pemahaman materi yang telah disampaikan oleh guru, sehingga hal ini bisa mempermudah guru untuk memberikan penilaian kepada peserta didik.

Hasil belajar peserta didik kelas III MI The Noor Dusun Pringwulung desa bendunganjati masih banyak yang mendapatkan nilai dibawah rata-rata, hal ini dikarenakan saat proses belajar mengajar berlangsung guru hanya menggunakan media konvensional dikarenakan sarana prasarana sekolah sehingga guru sulit memilih media yang akan digunakan dalam pembelajaran. Hal ini yang mengakibatkan peserta didik merasa jenuh dan tidak fokus saat mengikuti pembelajaran karena media yang digunakan oleh guru kurang menarik perhatian sehingga peserta didik sering ribut dan sibuk bercerita dengan teman sebangkunya. Dari hasil wawancara bersama guru kelas III yang dilakukan oleh penelititi pada tanggal 28 Desember 2020 didapatkan nilai tugas harian peserta didik masih banyak yang belum mencapai KKM, dari 16 peserta didik yang mencapai KKM hanya 5 peserta didik, selebihnya masih dibawah KKM (Ainun 2021), KKM di MI The Noor adalah 70.

Berdasarkan permasalahan tersebut peneliti mencoba membuat media pembelajaran yang menarik perhatian peserta didik yaitu media komik. Media komik ini disajikan sebagai salah satu alternatif untuk digunakan dalam pembelajaran, yang dimaksud dengan digunakannya komik dalam pembelajaran adalah bahwa materimateri dari pelajaran yang akan dipelajari dijadikan sebagai urutan cerita yang menarik, kemudian cerita tersebut divisualisasikan kedalam bentuk gambar kartun untuk memberikan kemudahan bagi peserta didik untuk memahami makna yang tersirat pada isi bacaan. Terpadunya antara isi bacaan dan gambar, dapat mempermudah peserta didik dalam mencerna isi bacaan tersebut. Sehingga peserta didik mampu menyimpulkan dan memahami isi bacaan itu. Permasalahan lain yang peneliti temukan yakni peserta didik juga lebih suka membaca buku yang memiliki akan kaya warna dan gambar seperti buku cerita, cerita bergambar, dan buku-buku komik, sehingga dengan adanya media komik ini peserta didik lebih senang dalam mengikuti proses belajar mengajar, dan juga meteri yang disajikan dalam komik cukup sederhana sehingga peserta didik dapat dengan mudah untuk memahami.

Media komik merupakan media suatu bentuk kartun yang menerapkan karakter dan memerankan suatu cerita dalam urutan yang erat dihubungkan dengan gambar dan dirancang untuk memberikan hiburan kepada para pembaca. Kartun sangat bergantung pada dampak penglihatan tunggal, oleh karena itu komik terdiri atas berbagai situasi cerita bersambun (Sumantri 2015). Kartun biasanya hanya menangkap esensi pesan yang harus disampaikan dan menuangkannya kedalam gambar sederhana. Kartun tanpa digambar detail dengan menggunakan simbol-simbol serta karakter yang mudah dikenal dan dimengerti dengan cepat. Kalau makna kartu bisa mengena, maka pesan yang besar bisa disajikan secara ringkas dan kesannya akan tahan lama dalam ingatan (Sadiman 2009).

(Sudjana and Rifa'i 2013) Komik dibedakan menjadi dau macam yaitu: Komik Strip adalah Komik strip adalah suatu bentuk komik yang terdiri dari beberapa lembar bingkai komik yang dimuat dalam suatu harian atau majalah dan biasanya ceritanya bersambung. 2) Komik Buku adalah komik yang berbentuk buku biasanya mempunyai cerita yang lebih panjang dan langsung selesai ataupun bersambung dan komik buku ini dapat mengantarkan cerita yang bertema sejarah, legenda, dan kisah-kisah kepahlawanan. Dalam menggunakan media komik tentunya terdapat kelebihan dan kekurangan, beberapa kelebihan media komik yaitu: 1) Komik menambah 
perbendaharaan kata-kata bagi pembacanya. 2) Mempermudah peserta didik untuk menagkap hal-hal yang masih abstrak. 3) Dapat mengembangkan minat baca peserta didik dalam belajarnya. beberapa kekurangan dalam penggunaan media komik yaitu sebagai berikut: 1) Kemudahan peserta didik membaca komik membuat malas membaca sehingga menyebabkan penolakan-penolakan atas buku-buku yang tidak bergambar. 2) Penyampaian materi pelajaran melalui komik terlalu sderhana. 3) Penggunaan media komik hanya efektif diberikan pada peserta didik yang bergaya visual (Sadiman 2009). Oleh karena itu dengan adanya kekurangan-kekurangan tersebut guru harus mampu mengatasinya agar proses belajar mengajar tetap berjalan sesuai dengan yang direncanakan.

Berdasarkan uraian diatas sesuai dengan penelitian yang dilakukan oleh Durotun Nasikhah bahwa ada pengaruh yang signifikan antara penggunaan media komik dengan minat belajar siswa, sehingga dapat disimpulkan bahwa media komik sangat cocok digunakan sebagai media dalam pembelajaran (Nasikhah 2019). Pendapat selanjutnya juga dikemukakan oleh Winny Sunfriska Limbong dan Pasti Rosion Natali Hutabarat ia juga mengatakan dalam tulisan journalnya bahwa terdapat pengaruh yang signifikan mengenai penggunaan media komik dalam pembelajaran (Limbong and Hutabarat 2021). Dari beberapa pendapat yang dikemukakan diatas tujuan dalam penelitian ini adalah untuk mengehatui pengaruh penggunaan media komik terhadap hasil belajar peserta didik kelas III tema I Subtema I di Madrasah Ibtidaiyah The Noor.

\section{METODE PENELITIAN}

Mengacu pada tujuan penelitian yaitu mengetahui pengaruh penggunaan media komik terhadap hasil belajar peserta didik kelas III Tema I Subtema I di MI The Noor, maka penelitian ini menggunakan metode kuantitatif dengan desain One group Pre-test Post-test Design. Desain ini terdiri atas satu kelompok yang telah ditentukan. Didalam rancangan ini dilakukan tes sebanyak dua kali, yaitu sebelum diberi perlakuan (pre-test) dan sesudah diberi perlakuan (post-test). Adapun pola desain penelitian one group pretest posttest design adalah sebagai berikut:

Keterangan:

\section{$\mathbf{O}_{1} \mathrm{X} \mathrm{O}_{2}$}

$\mathbf{0}_{1}$ Hasil belajar sebelum menggunakan media komik (Pre-Test)

X Pembelajaran menggunakan media komik

$\mathbf{0}_{2}$ Hasil belajar setelah menngunakan media komik (Post-Test)

Penelitian ini dilakukan pada tahun bulan Juli tahun ajaran 2021-2022 dengan teknik pengumpulan data wawancara dan tes. Adapun instrumen penelitian sebelum digunakan telah diuji validitas dan reliabilitas dengan menggunakan validasi isi dan konstruk, validasi isi dilakukan oleh dosen ahli dan untuk validasi konstruk menggunakan bantuan Microsoft Excel. Intrumen yang digunakan berupa soal tes dengan kriteria soal pilihan ganda dengan jumlah 10 butir soal dan isian berjumlah 5 soal.

Pengolahan data hasil belajar siswa diawali dengan soal pre-test yang kemudian hasilnya dirata-rata untuk mengetahui hasil sebelum dan sesudah diterapkan media pembelajaran berupa media komik. Selanjutnya untuk mengetahui sampel populasi berdistribusi normal maka dilakukan uji normalitas dengan menggunakan metode Lilifors yang merupakan penyempurnaan dari metode kolmogorov-smirnov sehingga lebih sifatnya lebih menyederhanakan dengan bantuan SPSS. 
Adapun dasar pengambilan keputusan dalam melakukan uji normalitas kolmogorovsmirnov yaitu: a) Jika nilai sig. > 0,05 maka data penelitian berdistribusi normal, b) Jika nilai sig. $<0,05$ maka data penelitian tidak berdistribusi normal.

Setelah uji normalitas dilakukan selanjutnya dilakukan uji Paired sampel T-test untuk mengetahui apakah ada perbedaan hasil belajar peserta didik sebelum dan sesudah diberikan perlakukan. Uji Paired sampel T-tes dilakukan dengan menggunakan bantuan SPSS, untuk dasar pengambilan keputusannya yaitu: a) Jika nilai sig. (2-tailed) $<$ 0,05 maka H0 ditolak dan Ha diterima, b) Jika nilai sig. (2-tailde) > 0,05 maka H0 diterima dan Ha ditolak.

\section{HASIL DAN PEMBAHASAN}

1. Pengujian Instrumen Penelitian

a. Uji Validitas Soal Pilihan Ganda

Tabel 1. Uji Validitas Soal Pilihan Ganda

\begin{tabular}{c|c|c|c}
\hline No. Butir Soal & r Hitung & r Tabel 5\% & Kriteria \\
\hline 1 & \#DIV/0! & & Tidak valid \\
2 & 0.419077532 & & Valid \\
3 & 0.53792 & & Valid \\
4 & 0.458083 & & Valid \\
5 & 0.461954 & & Valid \\
6 & \#DIV/0! & & Tidak valid \\
7 & 0.624342 & & Valid \\
8 & 0.697118 & $\mathbf{0 . 3 1 6}$ & Valid \\
9 & 0.53792 & & Valid \\
10 & \#DIV/0! & & Tidak valid \\
11 & 0.624342 & & Valid \\
12 & 0.697118 & & Valid \\
13 & 0.53792 & & Valid \\
14 & 0.458083 & & Valid \\
15 & 0.461954 & & Valid \\
\hline
\end{tabular}

Berdasarkan hasil uji validitas dari 15 soal pilihan ganda terdapat 3 soal yang tidak valid, sehingga item-item yang tidak valid tersebut tidak diikut sertakan dalam penelitian. Dalam hal ini peneliti hanya mengambil soal yang valid sebanyak 10 soal untuk dijadikan bahan penelitian.

b. Uji Validitas Soal Isian

Tabel 2. Uji Validitas Soal Isian

\begin{tabular}{cccc}
\hline $\begin{array}{c}\text { No. Butir } \\
\text { Soal }\end{array}$ & r Hitung & $\begin{array}{c}\text { r Tabel } \\
\mathbf{5 \%}\end{array}$ & Kriteria \\
\hline 1 & 0.657 & & Valid \\
2 & 0.669 & & Valid \\
3 & 0.581 & $\mathbf{0 . 3 1 6}$ & Valid \\
4 & 0.688 & & Valid \\
5 & 0.613 & & Valid \\
\hline
\end{tabular}

Berdasarkan hasil uji validitas tabel diatas dapat kita simpulkan bahwa masing-masing item soal tersebut adalah valid. Sehingga peneliti menggunakan soal tersebut untuk dijadikan bahan penelitian. 
c. Uji Reliabilitas Soal Pilihan Ganda

Tabel 3. Uji Reliabilitas Soal Pilihan Ganda

\begin{tabular}{ccc}
\hline Analisis & Hasil & Kategori \\
\hline $\mathrm{N}$ & 10 & \multirow{2}{*}{ Tinggi } \\
$\mathrm{r}_{11}$ & 0.621957 & \\
\hline
\end{tabular}

Dari tabel diatas didapatkan nilai $\mathrm{r}_{11}$ yaitu 0,621957 lebih besar dari 0,60. Maka dapat disimpulkan soal tersebut reliabel. Sehingga nilai 0,621957 tersebut disesuaikan dengan kriteria maka dapat diambil kesimpulan bahwa soal tersebut dikategorikan mempunyai reliabilitas yang tinggi.

d. Uji Reliabilitas Soal Isian

Tabel 4. Uji Reliabilitas Soal Isian

\begin{tabular}{ccc}
\hline Analisis & Hasil & Kategori \\
\hline $\mathrm{N}$ & 5 & Tinggi \\
$\mathrm{r}_{11}$ & 0.62654 & \\
\hline
\end{tabular}

Dari tabel diatas didapatkan nilai $\mathrm{r}_{11}$ yaitu 0.62654 lebih besar dari 0,60. Maka dapat disimpulkan soal tersebut reliabel. Sehingga nilai 0.62654 tersebut disesuaikan dengan kriteria maka dapat diambil kesimpulan bahwa soal tersebut dikategorikan mempunyai reliabilitas yang tinggi.

\section{Pengujian Hipotesis Penelitian}

Setelah instrumen penelitian divalidasi menggunakan validitas isi dan konstruk dan telah dinyatakan valid dan reliabel, selanjutnya instrumen penelitian diterapkan kepada peserta didik kelas III MI The Noor Pringwulung. Berdasarkan uji normalitas diperoleh hasil sebagai berikut.

Tabel 5. Hasil Uji Normalitas

\begin{tabular}{|c|c|c|c|c|c|c|c|}
\hline & \multirow[b]{2}{*}{ Kelas } & \multicolumn{3}{|c|}{ Kolmogorov-Smirnova } & \multicolumn{3}{|c|}{ Shapiro-Wilk } \\
\hline & & $\begin{array}{c}\text { Statisti } \\
\text { c }\end{array}$ & $\mathrm{df}$ & Sig. & $\begin{array}{c}\text { Statisti } \\
\mathrm{C}\end{array}$ & $\mathrm{df}$ & Sig. \\
\hline \multirow[t]{2}{*}{$\begin{array}{l}\text { Hasil Belajar } \\
\text { Siswa }\end{array}$} & $\begin{array}{l}\text { Pre } \\
\text { Tes }\end{array}$ & .185 & 16 & .145 & .921 & 16 & .176 \\
\hline & $\begin{array}{l}\text { Pos } \\
\text { Tes }\end{array}$ & .197 & 16 & .096 & .939 & 16 & .340 \\
\hline
\end{tabular}

Berdasarkan tabel hasil uji normalitas diatas dapat diketahui bahwa nilai Sig. > 0,05 sehingga dapat diartikan bahwa data yang digunakan dalam penelitian tersebut berdistribusi normal. Selanjutnya uji Paired Sampel T-test digunakan untuk mengetahui apakah terdapat pengaruh penggunaan media komik terhadap hasil belajar peserta didik. Berikut data hasil uji Paired Sampel T-tes. 
Tabel 5. Hasil Uji Paired Sampel T-tes

\begin{tabular}{|c|c|c|c|c|c|c|c|c|c|}
\hline & \multicolumn{5}{|c|}{ Paired Differences } & $\mathrm{t}$ & $\begin{array}{l}d \\
f\end{array}$ & $\begin{array}{l}\text { Sig. (2- } \\
\text { tailed) }\end{array}$ \\
\hline & & \multirow[b]{2}{*}{$\begin{array}{c}\text { Mea } \\
\mathrm{n}\end{array}$} & \multirow{2}{*}{$\begin{array}{l}\text { Std. } \\
\text { Devia } \\
\text { tion } \\
\end{array}$} & \multirow{2}{*}{$\begin{array}{l}\text { Std. } \\
\text { Error } \\
\text { Mean }\end{array}$} & \multicolumn{2}{|c|}{$\begin{array}{c}95 \% \\
\text { Confidence } \\
\text { Interval of the } \\
\text { Difference } \\
\end{array}$} & & & \\
\hline & & & & & $\begin{array}{l}\text { Low } \\
\text { er }\end{array}$ & Upper & & & \\
\hline $\begin{array}{l}\text { Pair } \\
1\end{array}$ & $\begin{array}{l}\text { Hasil Belajar } \\
\text { Pre Tes - } \\
\text { Hasil Belajar } \\
\text { Pos Tes }\end{array}$ & $\begin{array}{r}- \\
15.2 \\
50\end{array}$ & 5.651 & 1.413 & $\begin{array}{r}- \\
18.2 \\
61\end{array}$ & -12.239 & $\begin{array}{r}- \\
10.7 \\
95\end{array}$ & $\begin{array}{l}1 \\
5\end{array}$ & .000 \\
\hline
\end{tabular}

Berdasarkan tabel hasil uji Paired Sampel T-tes diatas didapatkan bahwa nilai Sig. (2-tailed) sebesar 0,000, yang artinya 0,000 $<0,05$ sehingga dapat diartikan bahwa $\mathrm{Ha}$ diterima dan HO ditolak. Dari penjelasan tersebut dapat disimpulkan bahwa ada perbedaaan hasil belajar peserta didik untuk pre-test dan post-test. Sehingga dapat disimpulkan pula bahwa "ada pengaruh penggunaan media komik terhadap hasil belajar peserta didik".

Penelitian ini meneliti tentang pengaruh penggunaan media komik terhadap hasil belajar peserta didik kelas III Tema I Subtema I tentang Pertumbuhan dan Perkembangan makhluk hidup, penelitian ini dilakukan di MI The Noor Dsn. Pringwulung Ds. Bendunganjati. Pada penelitian ini sampel yang digunakan adalah peserta didik kelas III yang berjumlah 16 peserta didik dengan rincian 11 laki-laki dan 5 perempuan. Sebelum peneliti memberikan perlakuan, terlebih dahulu peneliti memberikan uji soal Pre Tes kepada peserta didik guna untuk melihat kemampuan dan hasil belajarnya.

Penelitian ini dilakukan sebanyak empat kali pertemuan, setiap kali pertemuan 35 × 2 menit, yang dilaksanakan selama empat hari. Pada pertemuan pertama dilakukan uji soal Pre Tes sebelum pembelajaran dengan menggunakan media komik selanjutnya dilakukan pembelajaran menggunakan media komik hingga pertemuan keempat. Pada pertemuan keempat peserta didik kemudian diberikan Pos Tes guna untuk mengukur pemahaman dan hasil belajar setelah diberikan perlakuan dengan pembelajaran menggunakan media komik. Saat proses belajar mengajar yang dilakukan oleh peneliti dengan menggunakan media komik, namun peneliti tidak melupakan buku LKS siswa, karna dalam proses belajar mengajar media komik digunakan untuk menarik perhatian peserta didik agar peserta didik bisa mengikuti pembelajaran dengan serius, sehingga materi yang disampaikan dan materi yang ada didalam media komik tersebut bisa dipahami oleh peserta didik, sehingga peserta didik dapat memperoleh hasil belajar yang baik. Dalam penelitian yang peneliti lakukan disekolah MI The Noor ini, para peserta didik lebih gemar membaca buku yang memiliki cerita bergambar, sehingga saat peneliti melakukan pembelajaran menggunakan media komik, peserta didik lebih mudah mencerna isi yang ada dalam cerita tersebut, karena melihat watak peserta didik seperti itu peneliti membuat media komik untuk menarik perhatian peserta didik agar mau mengikuti pembelajaran dengan serius, dalam proses pembelajaran yang peneliti lakukan, peneliti tidak cenderung kedalam media komik saja, tetapi juga sambil menggunakan LKS yang telah disediakan sekolah, ketika peserta didik mulai jenuh, disitulah peran media komik dilakukan sehingga peserta didik lebih aktif saat mengikuti proses belajar mengajar. Setelah melihat hasil Pre-Test dan Post-Test yang telah peneliti berikan, ternyata peserta didik lebih aktif ketika saat proses pembelajaran menggunakan media komik, tidak hanya media LKS saja, hal ini dibuktikan 
dengan adanya peningkatan hasil ulangan peserta didik sebelum diberikan perlakuan dengan menggunakan media komik dan setelah diberikan perlakuan menggunakan media komik. Ratarata hasil ulangan peserta didik menggunakan media komik meningkat dibandingankan tidak menggunakan media komik.

Berdasarkan hasil uji yang dilakukan dengan menggunakan SPSS, bahwasanya terdapat perbedaan nilai antara Pre Tes dan Pos Tes. Diketahui nilai rata-rata Pre Tes sebesar 61.4 dan Pos Tes sebesar 76.6 sehingga dapat disimpulkan terdapat peningkatan hasil belajar peserta didik, yang artinya pembelajaran dengan menggunakan media komik berpengaruh terhadap hasil belajar peserta didik. Sehingga sesuai dengan tujuan penelitian yakni guna meningkatkan hasil belajar peserta didik.

\section{KESIMPULAN DAN SARAN}

Penelitian ini bertujuan untuk mengetahui adanya pengaruh penggunaan media komik terhadap hasil belajar peserta didik kelas III Tema I Subtema I di MI The Noor Pringwulung, didapatkan hasil belajar pesera didik sebelum diberikan pembelajaran menggunakan media komik memiliki rata-rata sebesar 61.4 dan setelah diberikan perlakukan didapatkan hasil belajar peserta didik sebesar 76.6, Sehingga dapat disimpulkan bahwa terdapat peningkatan hasil belajar peserta didik sebelum diberikan dan sesudah diberikan perlakuan.

Setelah dilakukan pengujian hipotesis dengan menggunakan Uji Paired sample Ttes didaptkan nilai Sig. (2-tailed) sebesar 0,000, dengan taraf signifikan 0,05, dilihat dari hasil analisis tersebut dapat diartikan bahwa terdapat pengaruh penggunaan media komik terhadap hasil peserta didik.

Diharapkan dalam melaksanakan proses belajar mengajar seorang guru harus bisa menciptakan proses belajar mengajar yang menyenangkan dan juga dalam pemilihan dan penggunaan media harus sesuai, agar peserta didik tidak meresa jenuh dengan pembelajaran yang dilakukan oleh guru. Dalam hal penelitian yang telah dilakukan, peneliti menyadari bahwa dalam penulisan skripsi ini masih sederhana, sehingga masih banyak kekurangan, diharapkan untuk peneliti selanjutnya mampu meneliti lebih baik lagi dari penelitian sebelumnya.

\section{UCAPAN TERIMAKASIH}

Ucapan terimakasih kami sampaikan kepada semua pihak yang telah mendukung penelitian ini sehingga bisa sampai tahap akhir, semoga kebaikan kita semua dibalas oleh Yang maha Kuasa Aamiin.

\section{REFERENSI}

Ahmad, Susanto. n.d. "Teori Belajar Dan Pembelajaran Di Sekolah Dasar - Dr. Ahmad Susanto, M.Pd. - Google Buku." Retrieved January 19, 2022 (https://books.google.co.id/books/about/Teori_Belajar_dan_Pembelajaran_di_Sek ola.html?hl=id\&id=IeVNDwAAQBAJ\&redir_esc=y).

Ainun, Elok. 2021."Hasil Wawancara.”

Amreta, M. Y., \& Safa'ah, A. (2021). Pengaruh Media PAPINKA terhadap Kemampuan Menghitung Penjumlahan dan Pengurangan dalam Pembelajaran Matematika di Sekolah Dasar. Jurnal Riset Madrasah Ibtidaiyah (JURMIA), 1(1), 21-28.

Anon. n.d. "View of Upaya Meningkatkan Motivasi Dan Hasil Belajar Melalui Problem Based Learning Dengan Powerpoint Di Sekolah Dasar." Retrieved January 18, 2022 (http://journal.unugiri.ac.id/index.php/jurmia/article/view/203/132). 
Limbong, W. S., and Pasti Rosion Natalia Hutabarat. 2021. "PENGARUH PENGGUNAAN MEDIA KOMIK TERHADAP HASIL BELAJAR SISWA PADA PELAJARAN IPA MATERI PERISTIWA ALAM DI KELAS II A SD SWASTA PERKUMPULAN AMAL BAKTI (PAB) 15 KELAMBIR LIMA T.A 2018/2019." Undefined. doi: 10.36294/PIONIR.V7I1.1868.

Nasikhah, Durotun. 2019. "Skripsi Pengaruh Penggunaan Media Komik Terhadap Minat Belajar Peserta Didik Mata Pelajaran Fikih Kelas III Di MI Nasrul Fajar Meteseh Kota Semarang."

Nurmawati, Nurmawati. 2016. "Evaluasi Pendidikan Islam.”

Riyana, C., and K. RI. 2012. “Media Pembelajaran.” 232.

Sadiman, Arief. 2009. Media Pendidikan, Pengertian, Pengembangan Dan Pemanfaatannya. Jakarta: PT. Rajagrafindo Persada.

Sudjana, Nana, and Ahmad Rifa'i. 2013. PENGEMBANGAN MEDIA PEMBELAJARAN Google Books. Bandung: Sinar Baru.

Sumantri, Mohammad Syarif. 2015. Strategi Pembelajaran Teori Dan Praktik Ditingkat Pendidikan Dasar. jakarta: rajawali pers.

Suttrisno, Suttrisno. 2021. "PENGARUH PEMANFAATAN ALAT PERAGA IPS TERHADAP KINERJA GURU SEKOLAH DASAR." Jurnal Ilmiah Pendidikan Dasar 8(1):77-90. doi: 10.30659/PENDAS.8.1.77-90.

UUD RI RI No. 41. 1999. "Presiden Republik Indonesia." Peraturan Pemerintah Republik Indonesia Nomor 26 Tahun 1985 Tentang Jalan 2003(1):1-5. 